\title{
Land Reform in the Republic of South Africa: Social Justice or Populism?
}

\author{
ARKADIUSZ ŻUKOWSKI \\ University of Warmia and Mazury in Olsztyn \\ Instytut Nauk Politycznych \\ Uniwersytet Warmińsko-Mazurski w Olsztynie \\ ul. Szrajbera 11 \\ 10-007 Olsztyn, Poland \\ arkadiusz.zukowski@uwm.edu.pl
}

\begin{abstract}
In the paper land reform in South African political discourse will be investigated, especially the process of its politicization. How the topic of land reform is used by political forces, especially the ruling party; the African National Congress and current President Jacob Zuma. Does the Republic of South Africa take a populist turn on land reform or is it some kind of social justice after the suppression of the apartheid era and decades before? The political disputes and decisions will be analysed in confrontations with the fundamentals and values of a democratic state as a guarantee of property rights, private ownership and free market principles (dilemma of the problem of willing buyer - willing seller). It will be necessary to present the historical background of land problem in the RSA. The problem will be investigated in connection with the socio-economic situation of the RSA. The study will also tackle the problem of social and economic inequality from the perspective of politics. In the paper, a mix of primary and secondary research methods of data collection and analysing will be used. Theoretical framework will be based on assumptions of political discourse and the paradigm of "classic" land reform.
\end{abstract}

Keywords: land reform; South Africa; social justice; populism; African National Congress; Jacob Zuma; Julius Malema 


\section{Introduction}

The Republic of South Africa (RSA), since 1961 the official name of South Africa, is a unique country on the African continent, especially when it comes to the cultural, social, economic and political realms. The specificity of the RSA relates to its history and the present day, especially to the so-called the New South Africa. ${ }^{1}$ The New South Africa is famous in the world after introducing democracy in a multi-race and multi-ethnic society (the idea of rainbow nation) and implementing social and economic programmes empowering non-white population, especially Africans (Blacks). Since 1994 there emerged the following programmes: Reconstruction and Development Programme - RDP (Lodge 2002: 54-69), Growth, Employment and Redistribution - GEAR ("Growth, Employment..." n.d.), Black Economic Empowerment - BEE ("How does the BEE..." n.d.), Broad-Based Black Economic Empowerment - B-BBEE ("Broad-Based Black..." 2004), Accelerated and Shared Growth Initiative for South Africa - ASGISA (The Accelerated and Shared Growth... 2006). The last one was prepared under the order of President Jacob Zuma and it presented strategy of socio-economic development of the RSA up to 2030 - National Development Programme (NDP) (National Development Plan 2011). The strategy comprises the issue of land redistribution and restitution in the context of effective land reform.

It is important to notice that the strategy underlines that:

the Constitution protects property rights and prevents confiscation of property without due compensation [...]. However, it also provides a legal, political and moral basis for redress measures such as land reform. Flowing from the Constitution, the White Paper on land allows for land redistribution, land restitution and tenure reform. The principles underpinning land reform are threefold: De-racialising the rural economy; Democratic and equitable land allocation and use across race, gender and class; A sustained production discipline for food security. (National Development Plan 2011: 144)

The problem is reflected to the name of South African ministry - Department of Rural Development and Land Reform (formerly the Department of Land Affairs).

\footnotetext{
${ }^{1}$ The term New South Africa was introduced in South Africa after the adaptation of the democratic Interim Constitution in December 1993, and disseminated in the media and literature after the first democratic election in April of 1994. Usually as a turning point in the creation of the New South Africa the first democratic elections in April of 1994 and swearing of Nelson Mandela as president of South Africa on May 10 of that year are considered. This term is used to emphasize the fundamental difference between South Africa during the apartheid period (years 1948-1990) and afterwards when forming a democratic South Africa.
} 


\section{General socio-economic situation}

The Republic of South Africa has a population estimated at 55.398.277 in the middle of 2017 ("South Africa Population" 2017). The median of age is equal to 26.2 years. It indicates that the South African population is predominated by a young generation what deeply affects the internal social, economic and political situation. The country belonged and still belongs to the extremely diverse racially, ethnically, linguistically and religiously society.

The South African economy was and is the average size - upper-middle income economy - in terms of GDP size, the RSA is the $25^{\text {th }}$ largest in the world ("South Africa: Fast Facts" 2012), estimated GDP in 2017 was 288 billion USD ("South Africa GDP..." n.d.). The RSA attains one of the highest GDP per capita (nominal) in Africa ( $7^{\text {th }}$ position), which amounted to 6.354 USD in 2014 ("List of African Countries..." 2014).

Despite the fact the RSA is still among the most important and richest countries on the African continent, it is not free from various negative economic and social problems. Besides widespread poverty, the issues are low level of education and health and other adverse phenomena.

Economic growth of the RSA is under African average, ${ }^{2}$ while the share of the RSA in world GDP gradually decreases. ${ }^{3}$ Consequently the RSA every year reduces its competitiveness in the global economy. ${ }^{4}$ Moreover, the value of the national currency (rand) against the US dollar in the last 25 years significantly decreased (especially after 1994), which results in a drop of the socio-economic conditions in the country. ${ }^{5}$

The RSA is struggling with high unemployment, officially its value is of at least 25\% ("South Africa unemployment: 1994-2015" 2015) - 2011- 24.8\%, 2012 24.9\%, 2013 - 24.7\%, 2014 - 25.2\% ("South Africa GDP..." n.d.), although estimates give even higher rate of $40 \%$. With high unemployment the shortage of highly qualified personnel (high-skilled workers) is currently up about 830.000 employees ("SA's economy..." n.d.).

\footnotetext{
${ }^{2}$ GDP annual growth rate in the RSA averaged 3.02\% between 1993 and 2015, estimated as low as $1.5 \%$ in 2015 in comparison with the average GDP growth of Sub-Saharan Africa of approximately $5.5 \%$ ("South Africa GDP Growth Rate" n.d.; "South Africa GDP..." n.d.

3 The RSA share in the world GDP decreased from $0.88 \%$ in 1989 to $0.65 \%$ in 2014 ("GDP as Share..." n.d., retrieved 15.08.2016).

${ }^{4}$ According to the classification conducted by the World Economic Forum in 2006 the RSA occupied $35^{\text {th }}$ position, in years 2008-2009 it was located on the $45^{\text {th }}$ place, in years 2013-2014 $-53^{\text {rd }}$ position, and in 2015 it declined at the $56^{\text {th }}$ position ("The Global Competitiveness Report 2008-2009" 2008: 500; “The Global Competitiveness Report 2014-2015" 2015: 13).

${ }^{5}$ In 1994 the value of the South African rand against the US dollar amounted to 1 USD = 3.55 ZAR; in $2014-1$ USD = 10.50 ZAR; in 20151 USD = 12.95 ZAR ("SA Rand Value..." 2015; "US Dollar..." n.d.).
} 
The United Nations estimates that one in eight adult South African are HIV positive, and in 2015, 180.000 people died because of AIDS ("HIV and AIDS in South Africa", retrieved 15.09.2016). According to the Human Sciences Research Council, based in Pretoria, the proportion of South Africans infected with HIV has increased from 10.6\% in 2008 to $12.2 \%$ in 2012 (the world highest rank) (Malan 2014).

In the RSA another vital problem is the growing number of social assistance beneficiaries (about $1 / 4$ of the country's population). Governmental administration is growing in staff numbers, which cause additional costs. Civil servants' salaries and benefits consume $35.5 \%$ of government's total budget, in the years 2008-2015 an additional 300.000 civil servants were employed, bringing the total amount to 1.6 million ("State of the Nation..." 2016).

Also, high crime adversely affects South African society. The country has presumably the highest rate of murders, assaults, rapes (not only committed on adults, but also on children and infants), and other crimes (especially robberies and property crimes) in comparison with other countries ("Factsheet: South Africa's Official..." n.d.). The highest crime rates are mainly reported in townships.

A huge issue in the RSA is corruption, ${ }^{6}$ especially in present political elite (e.g. the case of President of the RSA Jacob Zuma). Another arising problem is the growth of uncontrolled and massive migration processes, especially illegal emigration to the RSA, which increases the mood of xenophobia. This issue is very serious. According to the estimates, about 5 million illegal immigrants live in South Africa (Wilkinson 2015). After 1994, it has been an exodus of skilled Whites from the RSA, the phenomena of brain drain - 841.000 Whites emigrated between 1995 and 2005 alone (Visser 2007; Żukowski 2002: 349-357).

The poor socio-economic situation of the RSA, in the context of inequality, illustrates the indicators: Human Development Index (HDI) and GINI indicator. For the RSA in 2010 the HDI was 0.597, which placed the country low in the $110^{\text {th }}$ spot among 169 classified countries - 0 means the minimum value, and 1 is the maximum (Newham 2014). In terms of social justice, GINI index is important and measures the extent to which the distribution of income or consumption expenditure among individuals or households, within an economy deviates from a perfectly equal distribution. GINI index shows that income inequality continues to remain high for the RSA and amounts to 57.8 in $2009^{7}$ ("Human Development Report 2009" 2009). Although the downward trend of

\footnotetext{
${ }^{6}$ According to the Transparency International's 2013 Global Corruption Perception Index showed that "South Africa has dropped 34 places since 2001, with half the decline of 17 places occurring since 2009. South Africa is currently ranked at number 72 out of 175 countries and heading downwards" (Newham 2014).

${ }^{7} 0$ represents perfect equality, while the index of 100 implies perfect inequality.
} 
GINI can be observed: 2006 - 67.4, and between years 2005-2009 - 63.1 ("GINI Index..." n.d.). Still, this ratio is high per capita terms, e.g. amounted to 7.610 USD in 2012 (UNICEF n.d.).

According to the estimates of World Bank in 2011, 9.4\% of the South African society lived in extreme poverty - less than 1.25 USD per day ("Poverty \& Equity..." n.d.). Furthermore, according to the South African governmental National Planning Commission (NPC), the poverty percentage covered even $39 \%$ of the society in 2012 (Fonteyn and Davie 2014).

The problem is deepening due to current drought and the rise in food prices. The South African economy is slowing down and unemployment is rising.

\section{Land reform}

Land reform in the RSA is a very complex issue, rooted deeply in history, politics, race relations and socio-economic conditions. Land ownership is not only heritage of apartheid era but the decades earlier. The most important was the Native Land Act of 1913 which prohibited the land purchases by Africans outside of the scheduled Native Reserves. The process of dispossession of non-Whites, especially Africans culminated during apartheid (forced removal of approximately 3.5 million people). During the period of dismantling apartheid the Abolition of Racially Based Land Measures Act of 1991 was introduced.

In $1994,80 \%$ of the land was still owned by whites and 50.000 white farmers owned $85 \%$ of entire agricultural land. In this year the Restitution of Land Rights Act was passed, which commenced the land reform. The reform based on market-led approach "willing buyer - willing seller." The land would be bought from its owners (willing seller) by the government (willing buyer) and then redistributed, in order to maintain public confidence in the land market.

The issue of land reform was included in the Constitution of 1996 (Constitution of the Republic of South Africa 1996). Section 25(3) of the Constitution states: "[...] the amount of the compensation and the time and manner of payment must be just and equitable." Other paragraphs of the section says: "4a. the public interest includes the nation's commitment to land reform, and to reforms to bring about equitable access to all South Africa's natural resources; and [...]"; "5. The state must take reasonable legislative and other measures, within its available resources, to foster conditions which enable citizens to gain access to land on an equitable basis [...]"; " 8 . No provision of this section may impede the state from taking legislative and other measures to achieve land, water and related reform, in order to redress the results of past racial discrimination [...]". 
Sections 25(5) and (7) of the Constitution laid the foundations for land redistribution and land restitution respectively.

The land reform had three elements:

"- a land tenure reform programme that aims to address the insecurity of tenure, particularly in the former homelands, that arose during the apartheid era when the administration of land was often confused and chaotic;

- a land restitution programme that aims to restore land to those people who were displaced as a consequence of such acts as the Natives Land Act of 1913, and the Native Trust and Land Act of 1936;

- a land redistribution component that aims to redistribute land to the landless poor, labour tenants, farm workers, and emerging farmers for residential and productive uses, to improve their livelihoods and quality of life." (Bradstock 2004: V)

White Paper released in 1997 underlined three pillars of land reform: redistribution, restitution and tenure reform.

Restitution, whereby the government compensates (monetary) individuals who had been forcefully removed, has been very unsuccessful and the policy was shifted to redistribution. Redistribution was to be the main thrust of land reform, rapidly 'de-racialising' agriculture by creating a large number of emerging commercial farmers. So, in the RSA the idea of the land reform is coincident with the paradigm of 'classic' land reform, leading to land transfers from big to small farm (Lipton 2009: passim).

In the process of constructing and implementing land reform, not only the ruling ANC party was engaged but other domestic and foreign actors which mainly wished to maintain status quo (Weideman 2004: 219-238).

During the last years 'land reform' became a vital issue and 'hotspot' in political discourse in the RSA. The problem is highlighted by South African media.

In the years 1994-2014 more than 4.000 White farmers were killed in the RSA (Oneale 2014). The figures are higher than in Zimbabwe where the seize of white farms had a violent character. But the main message on land reform focuses on its failures and the negligence of expectations of poor Africans.

Because of apartheid, the demand for land redistribution, according to the principle: "Democratic and equitable land allocation and use cross race, gender and class," is therefore very difficult to fulfil (National Development Plan 2011). At the beginning of New South Africa in 1994 it was assumed as a target to redistribute $30 \%$ of land in five years. In fact, in the years 1994-2010 only 3.7\% 
of agricultural land has been allocated to new owners (in the first order to Africans) through land redistribution.

The government administration changed the deadline date of land reform to 2025. Land redistribution is a part of strategy of fighting against poverty and creation of new jobs (Polus 2014: 237).

Why populism is so attractive in the context of land reform? There is no real progress in implementing the goals of the land reform. Since 1994 only about 8 million hectares of the total of 86 million hectares of white-owned farms have been transferred to Africans - through land restitution and redistribution (Cousins 2016). The initial plan of the government was to transfer $30 \%$ of agricultural land from white farmers to Africans in the years 1994-1999 but the target was changed to 2014. And in 2014 (the Restitution of Land Rights Amendment Act) the deadline has been postponed for a period of five years.

By 2013, 4.12 million hectares had been redistributed from white owners to 230.886 black farmers and businessmen, which costed the government 12.9 billion rand - it means 1.4 billion USD (Nkwinti 2013).

Another problem is associated with a number of not resolved and not implemented restitution claims. There were about 20.000 settled restitution claims which have not been yet implemented. The government under pressure made amendments in the law in 2014 to allow new claims to be lodged up until 2019. President Jacob Zuma during his State of the Nation Address on 11 February 2016 mentioned a great number (about 120.000) new land claims (Etheridge 2016). Other sources report about 140.000 new land claims at the beginning of 2016 ("South Africa: Deputy Minister..." 2016). It is interesting that the vast majority of claims acquired not the land but a money compensation. ${ }^{8}$

\section{Radicalisation of discourse on land reform}

Above mentioned socio-economic situation favours the populism discourse on land reform. The populism discourse narration focuses mainly on still existed, race discrimination: rich white farmers versus poor rural Africans without land. The first one are villains and the second one victims. The land reform became a matter of historical and social justice, sovereignty of the state, and the real end of apartheid and the time of transition.

A quite new and important actor on the political stage in the discourse of land reform appeared just few years ago. Julius Malema, former ANC activist

8 "Official figures from 2013 show that an estimated 92\% of successful land claimants opted for cash rather than having their land restored to them" (Bhanga 2015). 
(president of the ANC Youth League from 2008 to 2012), ${ }^{9}$ formed a populist political party - the Economic Freedom Fighters (EFF) in 2013. ${ }^{10}$

Using populist slogans during the general election campaign in May 2014 EFF not only gained huge attention of media but also received so much as $6 \%$ of votes what spelled $25 \mathrm{MPs}$ in the National Assembly, including J. Malema.

Since two years J. Malema and the EFF begun a pseudo-communist rhetoric and inflammatory statements on land reform. They louder and louder call for expropriation of white farms without compensation for "equitable redistribution." J. Malema encourages the EFF supporters to "occupy land illegally and not apologize, as no white person in the country can claim ownership." He underlines that "all the land in South Africa belongs to the black majority" ("White people don't own..." 2016). In this way J. Malema and the EFF make political capital using racist language.

Because of the decline in social and economic conditions and stronger pressure from African radicals (mostly from J. Malema and his FEF and to lesser degree from left-wing of the African National Congress), the President and government are put under pressure to accelerate land reform.

The proposed new draft Bill (the Regulation of Land Holdings Bill) would limit the size of land ownership to 12.000 hectares and ban foreign nationals from owning the land (only long-term leases). Besides, the institution of "Office of the Valuer-General" was established from $1^{\text {st }}$ of September 2015 to determine land valuations in forced sales. Another proposal would compel white farmers to provide over a $50 \%$ share in their farms to African employees. This new instrument of land reform "Strengthening the Relative Rights of People Working the Land" is widely known as the 50/50 Policy Framework. Such propositions stated by the President gained support from many Africans. The problem of farm ownership by foreigners in the RSA is in fact not a relevant issue as they own only 3\% of total property in the country ("Land Ownership..." 2015).

The President started to question the fairness of land reform legislation, although the reform was approved by own the African National Congress government and even partially signed by himself, e.g. the Restitution of Land Rights Amendment Act of 2014 (Davies 2016).

The traces of populism in recent speeches of Jacob Zuma on land ownership are evident (years 2015-2016). There are more and more expressions on the subject as such slogans as: "The fate of too many is in the hands of too few" ("Land Ownership..." 2015), "Land has become one of the most critical factors in achieving redress for the wrongs of the past" ("South Africa's Zuma..." 2015),

\footnotetext{
${ }^{9}$ He was expelled from ANC in 2012 for sowing divisions in party by hate speeches ("Julius Malema..." 2014).

${ }^{10}$ About populism of J. Malema and the EFF (see more: Hurt and Kuisma 2016).
} 
"Black South Africans are poor because they have no land; most of it belongs to whites" (Du Preez 2016), "Whites had indeed stolen black people's land" (Du Preez 2016), "The very law that we have today to claim (land) is lopsided against black people" (Makinana 2016).

Experiences of land reform from neighbouring countries are also being shared. ${ }^{11}$ The land reform in Zimbabwe (especially after 2000 when farm land was seized not fully legally by war veterans) is treated as a warning for the RSA because it damaged Zimbabwe's economy. But there are positive opinions concerning Zimbabwean land reform during the'80's. ${ }^{12}$ Summing up, the experience of land reform in Zimbabwe provides a salutary lesson in the pitfalls of land expropriation (Luke 2015). Namibia, after gaining independence in 1990, started the land reform in 1994 but without full success, mainly because their constitution only allowed to buy the land from farmers willing to sell and the market price of land was high.

\section{Preliminary conclusions}

Present political situation and socio-economic conditions have created a fertile ground for the growth of populism in the RSA. The failure of concept of "Willing Buyer, Willing Seller" during the implementation of land reform resulted in much more populist statements and speeches. The social and economic situation of majority of Africans have not improved greatly after the collapse of apartheid. The transfer of majority of land from Whites to Blacks seems to be one element of social justice for harms and damages of colonialism, especially during the apartheid era.

Critics of land reform legislation and process in the context of social justice claims for more than decade the following: "The claims that dispossessed and poor South Africans are laying are legitimate. At the same time, there is no doubt that the market-led approach to land reform, including the protection of property rights in the Constitution and the 'willing buyer, willing seller' approach to land reform, will not unravel years of colonial and apartheid dispossession" (Ntsebeza 2007: 27).

Considering a social justice point of view, rely on Friedrich Hayek's concept, it could be useful to cite his opinion - "when governments (or other organizations)

\footnotetext{
${ }^{11}$ On redistributive land reform in Southern Africa (see more: Adams and Howell 2001; De Villiers 2003).

${ }^{12}$ According to Edward Lahiff: "Land reform in Zimbabwe in the 1980s was much more effective than reform in South Africa to date, because the government there engaged robustly in the land market, acquired reasonably good quality farms, restructured them to facilitate small-scale family farming and provided high levels of support to new farmers" ("Q\&A: Land Reform..." n.d.).
} 
violate people's rights by imposing discriminatory laws intervention may be necessary to correct the situation" (Boudreaux 2009), therefore "the social justice" argument is further beyond populist characteristic.

Considering the economic context, the radicalisation in conducting land reform may harm South African economy. According to the government estimates, about $90 \%$ of redistributed farms is not productive ("Land Ownership..." 2015). The current populist discourse on land reform clashes with the idea of a "Rainbow Nation."

Land reform still remains a very emotive topic, so it is expected to be frequently leveraged by radical politicians from EFF and by the South African President and government. The President and government will be under growing pressure to show that the implementation of land reform is really under way. While especially poor Africans experience frustration due to the slow pace of land reform. It could be supposed that extreme race rhetoric on land reform issue will be used.

The EFF, and in less extent the ANC, will play the Wit Gevaar [White Danger] card looking for either further new votes or to maintain support among Africans before general elections in 2019. Such a trend was observed before local municipal election which was held in August 2016 ("The Economic Freedom..." 2016). Agriculture is the prime source of income for as many as 5 million people and their dependants in the RSA, so their votes cannot be taken for granted.

The President and ANC ruling party begins to talk on more radical social and economic transformations, with special emphasis on land reform. The pressure on the President and ANC will continue to grow and introduce more radical methods of land redistribution. From the other side, some non-governmental organizations as PLAAS calls for "constructive national dialogue about the future of the rural areas, and the role of land reform in this crucial process" ("Beyond Populism..." n.d.).

\section{Bibliography}

Adams, Martin, and John Howell. 2001. "Redistributive Land Reform in Southern Africa." ODI. Natural resources perspectives 64: 1-6. 15 Nov. 2016. <https://www.odi.org/sites/ odi.org.uk/files/odi-assets/publications-opinion-files/2831.pdf>.

"Beyond Populism or Paralysis: Engaging Civil Society in Policy Dialogue about the Green Paper on Land Reform and Rural Development." n.d. 15 Nov. 2016. <http://www. plaas.org.za/civil-society-engagement/beyond-populism-or-paralysis-engaging-civil-society-policy-dialogue-about>.

Bhanga, Nqaba. 18 Feb. 2015. "We Need Bold Moves on Land Reform, Not Populism." 15 Nov. 2016. <https://www.da.org.za/2015/02/south-africa-deserves-da-government-serious-accelerated-effective-land-reform/ $>$. 
Boudreaux, Karol C. 2009. "Land Reform as Social Justice: The Case of South Africa." Mercatus Center Working Paper 9(37). 15 Nov. 2016. <http://works.bepress.com/karol _boudreaux/27/>.

Bradstock, Alastair. 2004. "Implementing Land Reform in South Africa's Northern Cape Province." Agren Network Paper 137. 15 Nov. 2016. <https://www.odi.org/sites/odi. org.uk/files/odi-assets/publications-opinion-files/5184.pdf >.

“Broad-Based Black Economic Empowerment Act, 2003, No. 53 of 2003." 2004. Government Gazette 463. 9 January 2004. No. 25899.

Constitution of the Republic of South Africa. 1996. 14 March 2017. <http://www.gov.za/ documents/constitution/chapter-2-bill-rights\#25>.

Cousins, Ben. 1 June 2016. "Why SA Needs Fresh Ideas to Make Land Reform a Reality." 14 March 2017. <http://www.fin24.com/Economy/why-sa-needs-fresh-ideas-to-make-land-reform-a-reality-20160601>.

Davies, Gaye. 2016. "Zuma Questions Fairness around Land Reform Legislation." 14 March 2017. <http://ewn.co.za/2016/03/04/Zuma-questions-fairness-around-land-reform-legislation>.

Etheridge, Jenna. 2016. "Land Reform Remains Important for Transformation - Zuma." 14 March 2017. <http://www.fin24.com/Economy/land-reform-remains-important-for-transformation-zuma-20160211>.

"Factsheet: South Africa's Official Crime Statistics for 2013/14." n.d. 14 March 2017. $<$ https://africacheck.org/factsheets/ factsheet-south-africas-official-crime-statistics-for-201314/>.

Fonteyn, Yvonne, and Lucille Davie. 21 Jan. 2014. “A Vision for 2030: South Africa's National Development Plan." 15 Sept. 2016. <http://www.mediaclubsouthafrica.com/democracy/3655-a-vision-for-2030-south-africa-s-national-development-plan\#ixzz3m51E99Dc>.

"GDP as Share of World GDP at PPP by Country." n.d. 15 Sept. 2016. <https://www. quandl.com/collections/economics/gdp-as-share-of-world-gdp-at-ppp-by-country>.

“GINI Index (World Bank estimate)." n.d. 15 Sept. 2016. <http://data.worldbank.org/ indicator/SI.POV.GINI?page $=1>$.

"Growth, Employment and Redistribution. South African Economic Plan." n.d. Encyclopaedia Britannica. 15 Sept. 2016. <http://www.britannica.com/topic/Growth-Employment-and-Redistribution>.

"HIV and AIDS in South Africa." n.d. 15 Sept. 2016. < http://www.avert.org/safricastats. htm>.

“How Does the BEE Social Programme Work?" n.d. 15 Sept. 2016. <http://www.bee. co.za/content/Information.aspx>.

"Human Development Report". 2009. UNDP. 15 Sept. 2016. <http://hdrstats.undp. org/en/indicators/161.html>.

Hurt, Stephen R., and Mikko Kuisma. 2016. “Undermining the 'Rainbow Nation'? The Economic Freedom Fighters and Left-wing Populism in South Africa" (paper prepared for $66^{\text {th }}$ Political Studies Association Annual International Conference Hilton Brighton Metropole, Brighton 21-23 March 2016. 14 March 2017. <https://www.psa.ac.uk/ sites/default/files/conference/papers / 2016/Hurt\%20Kuisma\%20PSA\%20Paper\%20 2016.pdf>.

“Julius Malema of South Africa's Economic Freedom Fighters: A Profile." 30 Sept. 2014. 15 Sept. 2016. <http://www.bbc.com/news/world-asia-pacific-14718226>. 
"Land Ownership: South Africa Takes a Populist Turn on Land Reform." 2015. The Economist. 28 Feb. 2015. 15 Sept. 2016. <http://www.economist.com/news/middle-east-and-africa/21645232-south-africa-takes-populist-turn-land-reform-i-had-farm-africa>.

Lipton, Michael. 2009. Land Reform in Developing Countries: Property Rights and Property Wrongs. New York: Routledge.

"List of African Countries by GDP per Capita." n.d. 22 Apr. 2015. <http://statisticstimes. com/economy/african-countries-by-gdp-per-capita.php>.

Lodge, Tom. 2002. "The RDP: Delivery and Performance." Politics in South Africa: From Mandela to Mbeki. Lodge, Tom. Cape Town: New Africa Books. 54-69.

Luke, Leighton G. 9 Apr. 2015. "Challenges Confronting South Africa: Land Reform." Strategic Analysis Paper. 15 Sept. 2016. <http://futuredirections.org.au/wp-content/ uploads/2015/04/Challenges_Confronting_South_Africa_-_Land_Reform.pdf $>$.

Makinana, Andisiwe. 4 March 2016. "South Africa: Zuma Is in Trouble and Presses 'Radical Land Reform' Button.” 15 Sept. 2016. <https://africajournalismtheworld. com/2016/03/04/33930/>.

Malan, Mia. 1 Apr. 2014. "SA Has Highest Number of New HIV Infections Worldwide: Survey." The MailEGuardian. 22 Apr. 2016. <http://bhekisisa.org/article/2014-04-01-sa-holds-highest-number-of-new-hiv-infections-worldwide-survey>.

National Development Plan. Vision for 2030. 11 Nov. 2011. National Planning Commission, Pretoria.

Newham, Gareth. 17 Jan. 2014. "Why Is Corruption Getting Worse in South Africa." 12 Sept. 2016. <http://www.corruptionwatch.org.za/why-is-corruption-getting-worse-in-south-africa/>.

Nkwinti, Gugile. 2013. "Building Vibrant, Equitable, and Sustainable Rural Communities." Speech to Parliament, 19 February 2013. Cape Town.

Ntsebeza, Lungisile. 2007. "Land Redistribution in South Africa: The Property Clause Revisited." 15 Sept. 2016. <http://www.yale.edu/macmillan/apartheid/apartheid_ part1/Land_Reform.pdf $>$.

Oneale, Laura. 18 Apr. 2014. “South Africa White Genocide Escalates. International Groups Seek Solution." Liberty Voice. 22 Apr. 2014. <http://www.radiofreesouthafrica.com/south-africa-white-genocide-escalates-international-groups-seek-solution/>.

Polus, Andrzej. 2014. "Reforma rolna w Republice Południowej Afryki." Konteksty bezpieczeństwa w Afryce. Problemy globalne, sektorowe, regionalne, lokalne. Ed. Arkadiusz Żukowski. Olsztyn: Forum Politologiczne 16. 237.

"Poverty \& Equity. South Africa." n.d. World Bank. 15 Sept. 2016. <http:// povertydata. worldbank.org/poverty/country/ZAF>.

Preez Max, du. 19 Apr. 2016. “Playing the Wit Gevaar Game.” 15 Sept. 2016. <http:// www.news24.com/Columnists / MaxduPreez/playing-the-wit-gevaar-game$-20160419>$.

“Q\&A: Land Reform in South Africa.” n.d. 15 Sept. 2016. <http://www.pbs.org/pov/ promisedland/land-reform-in-south-africa/>.

Republic of South Africa. 2006. The Accelerated and Shared Growth Initiative for South Africa. A Summary. Pretoria: Government Printer.

“SA Rand Value: 1994-2015." 2015. 15 Sept. 2016. <http://businesstech.co.za/news/ general/82273/sa-rand-value-1994-2015/>. 
“SA's Economy Desperately Needs High-skilled Workers.” n.d. 15 Sept. 2016. <http:// www.adcorp.co.za/NEws/Pages/SA\%E2\% 80\%99seconomydesperatelyneedshigh-skilledworkers.aspx>.

"South Africa: Deputy Minister Mcebisi Skwatsha: Rural Development and Land Reform Dept Budget Vote 2016/17." 2016. 15 March 2017. <http://allafrica.com/stories/ 201604270726.html>.

“South Africa: Fast Facts." 2012. 15 Sept. 2016. <http://www.southafrica.info/about/ facts.htm\#.VePd0SXtlHy\#ixzz3kMiJwmZx>.

"South Africa GDP and Economic Data." n.d. 2 June 2017. <https://www.gfmag.com/ global-data/country-data/south-africa-gdp-country-report $>$.

“South Africa GDP Growth Rate." n.d. 15 Sept. 2016. <http://www.tradingeconomics. com/south-africa/gdp-growth>.

“South Africa Population." 2017. 2 June 2017. <http://www.worldometers.info/world-population/south-africa-population>.

“South Africa Unemployment: 1994-2015." 2015. 22 Aug. 2016. <https://businesstech. co.za/news/general/77737/south-africa-unemployment-1994-2015/>.

“South Africa's Zuma Outlines Land Reform Plans." 14 Feb. 2015. 15 Sept. 2016. <http:// www.bbc.com/news/world-africa-31471427>.

"State of the Nation Address: What Zuma Needs to Tell SA." 10 Feb. 2016. The Conversation. 15 Sept. 2016. <http://mg.co.za/article/2016-02-10-state-of-the-nation-address-what-zuma-needs-to-tell-sa>.

“The Economic Freedom Fighters Local Government Elections Manifesto." 2016. 15 March 2017. <http://www.effonline.org/eff-elections-manifesto-2016>.

The Global Competitiveness Report 2008-2009. 2008. World Economic Forum: Geneva.

The Global Competitiveness Report 2014-2015. 2015. World Economic Forum: Geneva.

UNICEF. n.d. "South Africa: Statistics." 15 Sept. 2016. <http://www.unicef.org/infobycountry/southafrica_statistics.html>.

“US Dollar to South African Rand Exchange Rate." n.d. 15 March 2017. <http://ycharts. com/indicators/south_african_rand_exchange_rate>.

Villiers, Bertus de. 2003. "Land Reform: Issues and Challenges. A Comparative Overview of Experiences in Zimbabwe, Namibia, South Africa and Australia." Konrad Adenauer Foundation Occasional Papers. 15 Sept. 2016. <http://www.kas.de/wf/doc/kas_2703-1522-2-30.pdf?040114114341)>.

Visser, Wessel. 2007. "Post-Hegemonic Afrikanerdom and Diaspora. Redefining Afrikaner Identity in Post-Apartheid South Africa." 15 Sept. 2016. <http://sun025.sun. ac.za/portal/page/portal/Arts/Departemente1/geskiedenis/docs/moskoureferaat. pdf $>$.

“White People Don't Own the Land - So Take It: Malema. 27 June 2016. 15 Sept. 2016. <http://businesstech.co.za/news/government/128169/white-people-dont-own-the-land-so-take-it-malema/>.

Weideman, Marinda. 2004. "Who Shaped South Africa's Land Reform Policy?." Politikon 2(31): 219-238. 15 Sept. 2016. <https://wikileaks.org/gifiles/attach/169/169043_ Land\%20Reform\%2011.pdf>.

Wilkinson, Kate. 6 May 2015. "Do Five Million Immigrants Live in SA?." The MailEGuardian. 15 Sept. 2016. < http://mg.co.za/article/2015-05-06-do-5-million-immigrants-live-in-sa>. 
Żukowski, Arkadiusz. 2002. "Exodus białych z Republiki Południowej Afryki do krajów Unii Europejskiej jako przykład międzykontynentalnych migracji doby globalizacji." Unifikacja i różnicowanie się wspótczesnej Europy. Eds. Barbara Fijałkowska, and Arkadiusz Żukowski. Warszawa: Elipsa. 349-357. 